\title{
PEMBERDAYAAN PAGUYUBAN BATIK PENDOPO DESA JARUM BERBASIS KOMUNIKASI PEMASARAN VIRTUAL DI ERA PANDEMI COVID-19
}

\author{
Puji Lestari ${ }^{1}$, Titik Kusumantini², Elisabet Isyana Rahayu ${ }^{3}$, Devi Wening \\ Astari4, Muhammad Irfan5 \\ 1,2,3,4,5Universitas Pembangunan Nasional "Veteran" Yogyakarta \\ ${ }^{1}$ E-mail address puji.lestari@upnyk.ac.id; \\ 2E-mail address kusumantini titik@yahoo.co.id; \\ 3E-mail address elisabethisyana@gmail.com ; \\ 4E-mail address devi wening@ymail.com; \\ 5E-mail address muhammadirfan3497@gmail.com
}

\begin{abstract}
Virtual marketing communication is still something new for the Paguyuban Batik Pendopo Desa Jarum. Marketing is usually done only through word of mouth and occurs offline. However, due to the COVID19 pandemic, tourist visits to Jarum Village have greatly decreased. Virtual-based marketing communications are needed to survive in this uncertain situation. With an association that accommodates UMKM, the potential to switch from conventional marketing communications to virtual marketing communications is very high. This service stage starts from discussions with community members of Paguyuban Batik Pendopo Desa Jarum, understanding community members about the importance of virtual marketing communication, assistance in making profile videos, assistance in making websites and blogs, and assistance in creating e-commerce accounts. The contribution made in this service is the assistance of the Paguyuban Batik Pendopo Desa Jarum in virtual marketing communications, especially in the era of the COVID-19 Pandemic.
\end{abstract}

Keywords : Paguyuban Batik Pendopo Desa Jarum, Virtual Marketing Communication, UMKM

\begin{abstract}
Abstrak
Komunikasi pemasaran virtual masih menjadi sesuatu yang baru bagi Paguyuban Batik Pendopo Desa Jarum. Pemasaran yang biasa dilakukan hanya melalui word of mouth dan terjadi secara offline. Namun, adanya pandemi COVID-19 membuat kunjungan wisatawan ke Desa Jarum sangat menurun. Diperlukan komunikasi pemasaran berbasis virtual untuk dapat bertahan di situasi yang tidak menentu ini. Dengan paguyuban yang mewadahi para UMKM, potensi untuk beralih dari komunikasi pemasaran konvensional ke komunikasi pemasaran virtual sangat tinggi. Tahapan pengabdian ini dimulai dari diskusi bersama
\end{abstract}


anggota paguyuban, pemahaman anggota Paguyuban Batik Pendopo Desa Jarum mengenai pentingnya komunikasi pemasaran secara virtual, pendampingan pembuatan video profil, pendampingan pembuatan website dan blog, dan pendampingan pembuatan akun $e$-commerce. Kontribusi yang dilakukan dalam pengabdian ini adalah pendampingan Paguyuban Batik Pendopo Desa Jarum dalam komunikasi pemasaran virtual khususnya di era Pandemi COVID-19.

Kata Kunci: Paguyuban Batik Pendopo Desa Jarum, Komunikasi Pemasaran Virtual, UMKM

\section{PENDAHULUAN}

Keberadaan usaha mikro kecil dan menengah (UMKM) telah mampu mengatasi pengangguran dan peningkatan pendapatan (Kancana, Lestari dan Nurficahyanti: 2016). UMKM secara makro, bahkan membantu pemerataan pertumbuhan ekonomi di Indonesia, terlebih ekonomi mikro di pedesaan. Kegiatan ekonomi rakyat berskala kecil, termasuk UMKM, perlu dilindungi untuk mencegah persaingan usaha yang tidak sehat. Merujuk pada Kepres Keputusan Presiden RI No. 99 Tahun 1998, perhatian dan kepedulian perlu dilakukan untuk menjamin berlangsungnya bisnis UMKM.

Pendampingan UMKM dinilai penting lantaran adanya pergeseran pertumbuhan ekonomi daerah yang tadinya bertumpu pada sektor pertanian berubah ke sektor industri (Ishack, 2004). Salah satu program pendampingan dan pemberdayaan UMKM dilakukan di Kecamatan Bayat, Klaten. Hal tersebut dikarenakan indeks kemiskinan Kecamatan Bayat terdata paling tinggi di Kabupaten Klaten, yakni sebanyak 9.638 KK berada di bawah garis kemiskinan (Pemerintah Daerah Kabupaten Klaten, 2018).

Berbagai usaha tumbuh di Kecamatan Bayat, di antaranya; batik, lurik, keramik dan industri makanan olahan. Usaha batik tulis menjadi salah satu yang memiliki pertumbuhan pesat dan potensial sebagai produk unggulan di beberapa desa, khususnya di Desa Jarum. Kondisi Desa Jarum yang merupakan lahan pertanian tadah hujan sehingga menjadikan masyarakat tidak dapat bergantung sepenuhnya dari sektor pertanian. Kondisi inilah yang mendorong masyarakat untuk lebih fokus pada usaha turun menurun yang ada, yakni membatik. 
Peran pemerintah daerah untuk mengembangkan wilayah Kecamatan Bayat dilakukan lintas sektor, yakni antara Badan Perencanaan dan Pengembangan Daerah, Dinas Pariwisata dan Dinas Perindustrian dan Perdagangan melalui program pengembangan usaha mikro khususnya dikawasan pedesaan. Dinas Pariwisata Kabupaten Klaten dalam mendukung pertumbuhan ekonomi desa telah mengambil kebijakan dengan menetapkan Desa Jarum sebagai desa wisata berbasis budaya. Penetapan ini didasari pada nilai tambah Desa Jarum sebagai sentra kerajinan batik tulis, baik dengan media kain, kayu maupun kulit.

Program pemerintah daerah direaliasaikan melalui pemberian sejumlah dana untuk perbaikan infrastruktur serta sarana dan prasarana sebagai desa wisata, seperti showroom bagi perajin. Di tingkat Desa Jarum, pelaku usaha batik tulis kain, kayu dan kulit tergabung dalam "Paguyuban Batik Pendopo Desa Jarum”. Paguyuban dimanfaatkan sebagai wadah bagi pelaku UMKM untuk berbagi informasi, pengetahuan, dan memfasilitasi kegiatan pemasaran kolektif. Kuatnya hubungan sosial antar pelaku usaha menjadi satu sumber daya strategis.

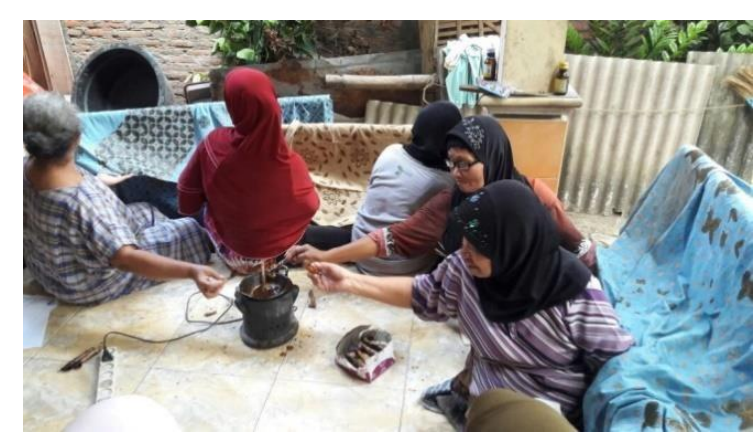

Gambar 1. Praktik membatik dengan warna alam

Produk batik paguyuban ini telah dikenal baik di pasar nasional maupun internasional, namun kemampuan pemasaran UMKM secara mandiri dan bebasis emarketing masih terbatas. Kondisi ini diperparah oleh pandemi COVID-19. Sebagai desa wisata, selama ini sentra batik di Desa Jarum banyak mengandalkan penjualan retail dari wisatawan yang datang. Pandemi COVID-19 telah membuat sektor pariwisata berhenti total, sehingga hampir tidak ada kunjungan. Di sisi lain, kemampuan pemasaran berbasis virtual sejauh ini belum dikembangkan secara optimal. Padahal, paguyuban mempunyai sumber daya strategis sebagai modal utama untuk meningkatkan kemampuan inovasi pemasaran virtual.

Pemasaran dengan pemanfaatan internet perlu ditingkatkan. Saat ini 
pemasaran tidak hanya dapat dilakukan secara konvensional bertemu langsung dengan pembeli, namun dapat dilakukan secara online. Ditambah dengan adanya pandemi COVID-19 yang mengharuskan untuk mengurangi mobilitas, komunikasi pemasaran virtual dianggap perlu dan harus dilakukan oleh setiap UMKM maupun bisnis dalam skala besar, Hal tersebut sesuai dengan penelitian terdahulu yang dilakukan oleh Sari dan Nadia (2021) yang menyatakan bahwa perusahaan bisnis telah melakukan perencanaan dan evaluasi dalam pengembangan komunikasi pemasaran secara virtual.

\section{METODE DAN PELAKSANAAN}

\section{Metode}

Pelaksanaan program pengabdian melibatkan berbagai pihak. Selain mitra sebagai sasaran program, pengusul juga melibatkan pihak ketiga dalam mencapai target luaran yang ditentukan. Untuk pengimplementasian aspek teknologi komunikasi pemasaran, dilibatkan pihak-pihak yang ahli di bidang komunikasi pemasaran virtual, mulai teknis strategi pemasaran hingga pembuatan konten komunikasi pemasaran. Sementara implementasi aspek managerial dilibatkan pihakpihak yang ahli di bidang manajemen organisasi dan penataan laporan keuangan. Adapun tahapan metode penerapan teknologi di Paguyuban Batik Pendopo Desa Jarum dimulai dari identifikasi sejauh apa pengetahuan mitra tentang konsep manajemen organisasi dan keuangan serta manajemen pemasaran dan komunikasi pemasaran virtual.

Langkah-langkah pendampingan yang akan dilakukan dalam menyelesaikan permasalahan yang dialami mitra adalah FGD dalam peningkatan pemahaman pengetahuan tentang komunikasi pemasaran virtual. Selanjutnya, dengan membuat video profil paguyuban dalam memperkuat brand dan mengunggahnya di website, blog serta media sosial yang dimiliki mitra. Pembuatan website dan blog juga masuk dalam langkah-langkah pendampingan. Dalam website tersebut diintegrasikan secara langsung ketika pengguna website ingin melakukan transaksi. Pembuatan pembayaran digital pun dilakukan untuk dapat menunjang tersebut.

\section{Pelaksanaan Kegiatan}

Pengabdian kepada masyarakat ini dilakukan di Desa Jarum, Bayat, 
Klaten pada akhir Mei 2021 hingga akhir September 2021. Pelaksanaan kegiatan dalam pengabdian masyarakat diberikan kepada Paguyuban Batik Pendopo Desa Jarum. Anggota dari Paguyuban Batik Pendopo Desa Jarum adalah pengrajin-pengrajin batik, baik batik tulis, batik cap, batik dengan pewarna alami maupun sintetik, accessories batik seperti dompet ataupun tas batik, hingga batik kayu.

Dalam Paguyuban Batik Pendopo Desa Jarum terdapat beberapa Kelompok Usaha Bersama (Kube) yang menjadi sasaran dalam pengabdian masyarakat ini.

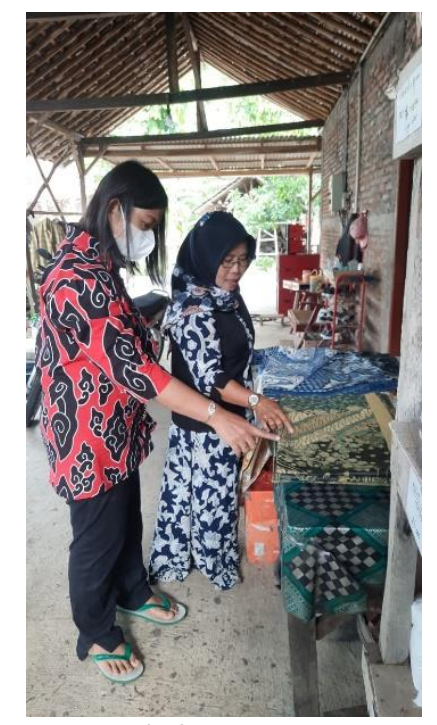

Gambar 2. Penjelasan mengenai warna alam

Pelaksanaan

kegiatan pengabdian diawali dengan diskusi atau focus group discussion (FGD) bersama dengan seluruh anggota paguyuban. Dengan diskusi tersebut, pengabdi melakukan map mapping sebelum akhirnya melakukan beberapa tahapan pendampingan untuk dapat menyelesaikan permasalahan yang dihadapi oleh mitra. Pada saat diskusi, anggota paguyuban sangat antusias dan mengungkapkan permasalahan mitra, khususnya perjuangan mereka di masa pandemi COVID-19.

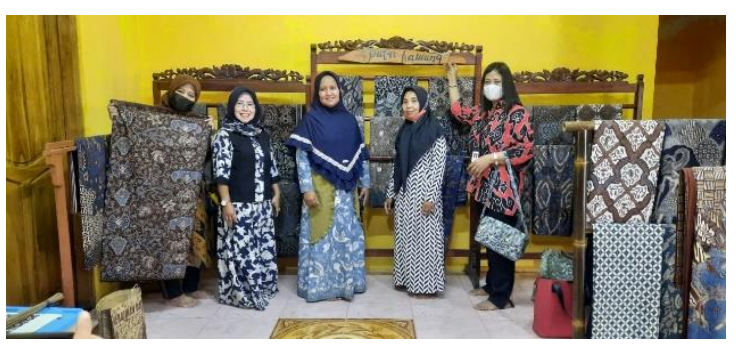

Gambar 3. Foto bersama anggota dan produk anggota paguyuban

\section{HASIL DAN PEMBAHASAN}

\section{Hasil}

Hasil dari identifikasi melalui focus group discussion di Paguyuban Batik Pendopo Desa Jarum adalah mendapatkan beberapa tahapan pendampingan. Pendampingan pertama dimulai dari pemahaman pentingnya mengelola usaha dengan pemasaran komunikasi virtual, khususnya di masa pandemi COVID19. Pada pendampingan pertama, pengabdi mendapatkan data mengenai anggota-anggota paguyuban yang masih eksis dan bertahan khususnya di era Pandemi COVID-19.

Dalam FGD yang dilakukan 
pengabdi juga memberikan pembuatan video, pengabdi pemahaman mengenai pentingnya memberikan penekanan pada history komunikasi virtual dengan berbagai platform seperti website, media sosial, dan e-commerce khususnya dalam menghadapi krisis yang disebabkan oleh pandemi COVID-19. Dari FGD yang dilakukan ini nantinya pengabdi melakukan pemecahan masalah sesuai dengan yang dibutuhkan oleh mitra.

Pendampingan kedua dilakukan dengan pembuatan video profil untuk anggota dari Paguyuban Batik Pendopo Desa Jarum. Dalam video ini, pengabdi mengajak mitra untuk dapat berkolaborasi sehingga mendapatkan video yang sesuai dengan yang dari usaha tersebut, produk yang ditawarkan, dan cara mitra dalam memasarkan produk tersebut.

Permasalahan selanjutnya bagi mitra adalah bahwa media pemasaran yang mereka gunakan sangat terbatas, hanya sebatas mouth of word (WOM). Dengan adanya pandemi COVID-19, membuat pemasaran WOM berhenti. Mitra merasa kesusahan untuk melakukan pemasaran. Oleh karena itu, pengabdi mendampingi mitra untuk pengelolaan website, blog, dan e-commerce dalam mempermudah pemasaran virtual.

dibutuhkan oleh mitra. Dalam

Tabel 1. Permasalahan dan Capaian

\begin{tabular}{|c|c|c|}
\hline No & Permasalahan Mitra & Capaian \\
\hline \multirow[t]{2}{*}{1} & $\begin{array}{l}\text { Daya jual menurun khususnya } \\
\text { adanya Pandemi COVID- } 19 \text {. }\end{array}$ & \multirow{2}{*}{$\begin{array}{l}\text { Membuat website, blog, } \\
\text { dan e-commerce bagi mitra } \\
\text { untuk dapat melakukan } \\
\text { pemasaran melalui media } \\
\text { komunikasi virtual. }\end{array}$} \\
\hline & $\begin{array}{l}\text { Pemasaran yang dilakukan } \\
\text { masih sebatas word of mouth. }\end{array}$ & \\
\hline 2 & $\begin{array}{l}\text { Kurangnya pemahaman } \\
\text { mengenai komunikasi virtual } \\
\text { dalam memasarkan produk. } \\
\text { Tidak adanya kegiatan promosi } \\
\text { media komunikasi virtual, } \\
\text { sehingga tidak ada konten dalam } \\
\text { komunikasi pemasaran. }\end{array}$ & 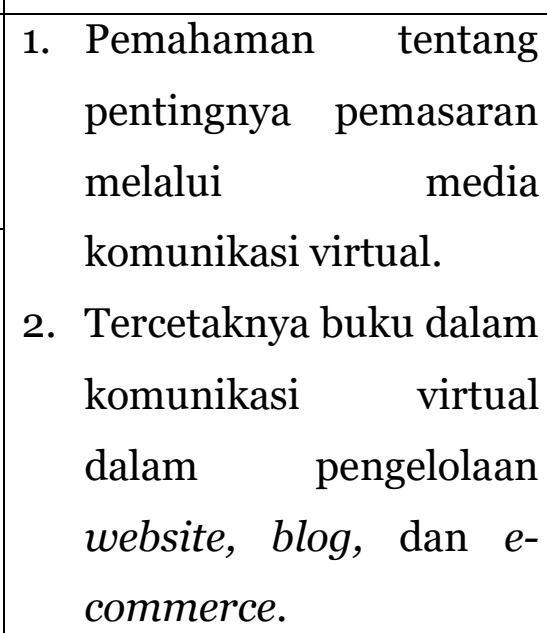 \\
\hline
\end{tabular}




\begin{tabular}{|c|lr|l|}
\hline & & $\begin{array}{l}\text { 3. Teruploadnya video- } \\
\text { video dalam website. }\end{array}$ \\
\hline 3 & $\begin{array}{l}\text { Keuangan dan sistem } \\
\text { pembayaran masih dikelola } \\
\text { secara manual. }\end{array}$ & $\begin{array}{l}\text { Menggunakan sistem } \\
\text { pembayaran digital. }\end{array}$ \\
\hline
\end{tabular}

Video profil yang telah dibuat nantinya akan diposting di website dan blog dari masing-masing pengrajin di Paguyuban Batik Pendopo Desa Jarum. Hal ini mampu untuk meningkatkan ketertarikan dari audience pada pengrajin dari Paguyuban Batik Pendopo Desa Jarum. Pengabdi melakukan pendampingan pada pembuatan website dan blog untuk meningkatkan penjualan. Website Paguyuban Batik Pendopo Desa Jarum tidak hanya menjadi media informasi mengenai galeri produk, tetapi juga menjadi media untuk melakukan penjualan secara langsung. Website tersebut memudahkan pengguna untuk berbelanja secara langsung tanpa harus berganti media.

Adanya peningkatkan penjualan sebesar 25\% selama pandemi COVID19 (Huda, 2020) melalui e-commerce, pengabdi melalukan pendampingan dalam pembuatan e-commerce dan memberikan pemahaman mengenai pentingnya menggunakan e-commerce dalam pemasaran di era digital khususnya di pandemi COVID-19.

Website, blog, dan e-commerce merupakan hal yang baru bagi mitra untuk melakukan pemasaran produk. Oleh karena itu, pengabdi memberikan sebuah buku panduan khusus untuk anggota Paguyuban Batik Pendopo Desa Jarum dalam mengelola dan menggunakan website, blog, dan $e^{-}$ commerce. Dengan pendampingan yang dilakukan, mitra mendapat manfaat dalam pemasaran yang dilakukan dengan media komunikasi virtual. Mitra juga lebih mengetahui dan memahami pentingnya komunikasi secara virtual dalam pemasaran di era Pandemi COVID-19.

\section{Pembahasan}

Kegiatan dalam pendampingan kepada Paguyuban Batik Pendopo Jarum, Bayat, Klaten dilaksanakan pada akhir bulan Mei hingga akhir September 2021 Tahap awal pelaksanaan pendampingan diawali dengan memberikan pemahaman kepada para anggota untuk meningkatkan pengetahuan tentang pentingnya manajemen keuangan dan 
komunikasi virtual. Dengan pengetahuan tersebut, diharapkan anggota mampu memiliki motivasi untuk mengatur keuangan dan mengarahkan pemasaran pada komunikasi virtual.

Pemahaman anggota Paguyuban Batik Pendopo Jarum terhadap pentingnya komunikasi virtual dalam pemasarannya terbangun ketika pengabdi bersama dengan Paguyuban Batik Pendopo Jarum mendiskusikan pentingnya komunikasi virtual khususnya karena adanya pandemi COVID-19.

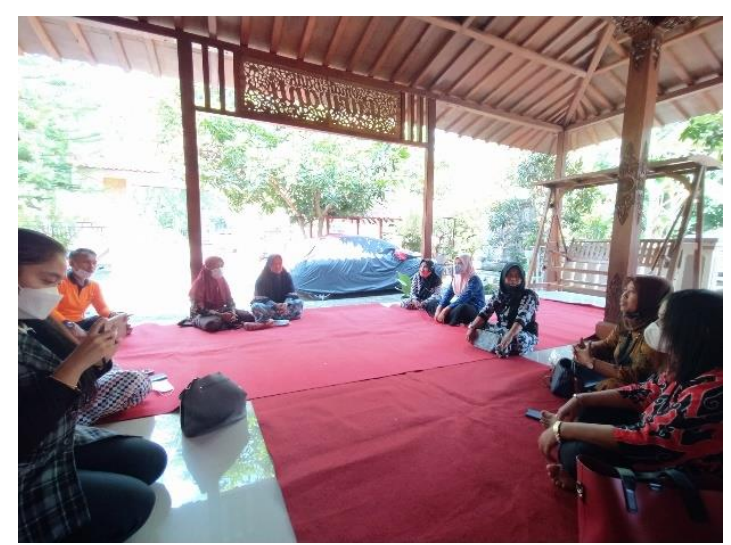

Gambar 4. FGD bersama anggota paguyuban

Implementasi

pengabdian

kepada Paguyuban Batik Pendopo Desa Jarum yang dilakukan disesuaikan untuk mengatasai masalah mitra. Pada pemetaan permasalahan mitra, dapat dibedakan menjadi 2 tipe yaitu permasalahan yang berhubungan dengan pengelolaan, sumber daya manusia, dan kendala yang berhubungan dengan komunikasi pemasaran secara virtual mengingat hal tersebut penting untuk dilakukan terlebih dalam situasi pandemi COVID-19 ini.

Dengan kendala-kendala yang terjadi pada mitra, pengabdi melakukan beberapa pendampingan mulai dari pembuatan video profil untuk komunikasi virtual, pembuatan website, dan pembuatan toko online di platform e-commerce Shopee. Dalam memberikan pendampingan tersebut, pengabdi juga memberikan pemahaman tentang pentingnya penggunaan media komunikasi virtual dalam proses pemasaran khususnya di masa pandemi COVID-19 ini.

Hasil dari pendampingan awal pangabdi kepada Paguyuban Batik Pendopo Jarum adalah bahwa Paguyuban Batik Pendopo Jarum memahami pentingnya komunikasi virtual untuk melakukan pemasaran secara online. Pendampingan selanjutnya yang dilakukan pengabdi adalah dengan pembuatan video profil untuk memperkuat merek dan pemasaraan secara online. Pada Paguyuban Batik Pendopo Jarum terdapat dua jenis batik yang dipasarkan yaitu batik yang dibuat di kain dan batik yang dibuat pada kayu atau sering disebut dengan batik kayu. 
Pengabdi membuat tiga video yaitu video mengenai profil Desa Jarum, profil Putri Kawung untuk batik kain, dan profil Cavin Craft untuk batik kayu.

Video profil Desa Jarum berdurasi 13 menit 29 detik dengan memperlihatkan suasana Desa Jarum, potensi Desa Jarum, pengetahuan mengenai jenis batik yang ada di Desa Jarum, penjelasan mengenai keunggulan batik di Desa Jarum, pengenalan paguyuban batik di Desa Jarum, menceritakan mengenai dampak pandemi COVID-19 terhadap pemasaraan produk di Desa Jarum, dan harapan kedepan untuk Desa Jarum terlebih anggota paguyuban Batik Pendopo dari perangkat desa.

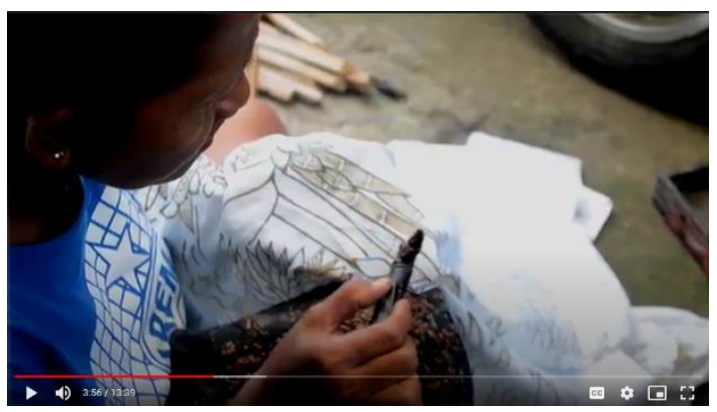

Gambar 5. Cuplikan di video profil

Desa Jarum

Video profil kedua adalah video profil Kelompok Usaha Bersama Putri Kawung. Dalam Paguyuban Batik Pendopo terdapat beberapa kelompok usaha bersama yang terdiri dari pengrajin-pengrajin batik. Salah satu kelompok usaha bersama yang sampai hari ini mash eksis adalah Kelompok Usaha Bersama (Kube) Putri Kawung. Oleh karenanya, pengabdi membuat video profil untuk membantu pemasaran dari Kube Putri Kawung. Video profil Kube Putri Kawung diawali dengan cerita awal mula berdirinya Kube Putri Kawung.

Selanjutnya, video memperlihatkan produk-produk yang dijual oleh kube ini, dan bagaimana pemasaran yang selama ini dilakukan. Pada akhir video, ketua Kube Putri Kawung memberikan harapannya untuk perkembangan Desa Jarum dan secara khusus untuk para pengrajin Kelompok Usaha Bersama (Kube) Putri Kawung.

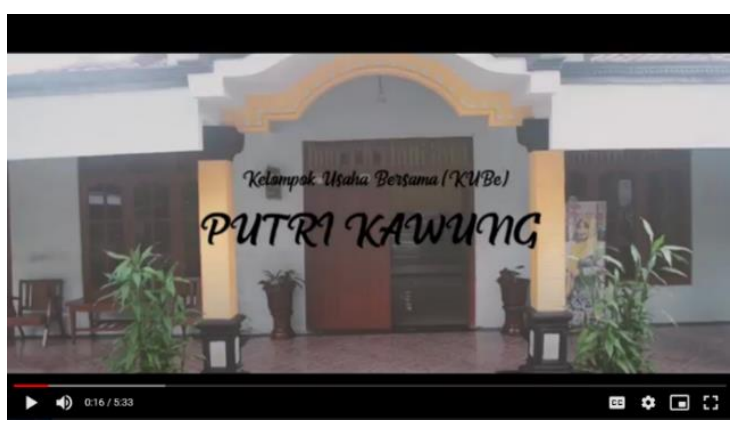

Gambar 6. Cuplikan di video profil Kube Putri Kawung.

Video profil ketiga yang dibuat oleh pengabdi adalah video profil usaha batik kayu Cavin Craft. Pengabdi mengambil video profil ini karena hasil diskusi bersama dengan Paguyuban Batik Pendopo Desa Jarum, Desa Jarum ingin menjadikan batik kayu sebagai daya tarik wisata Desa Jarum. 
Video awal terdapat narasi tentang perjalanan awal batik kayu Cavin Craft, produk-produk yang dipasarkan, pemasaran yang telah dilakukan, hingga harapan dari Cavin Craft terhadap perkembangan Desa Wisata di Jarum yang nantinya akan membawa dampak positif kepada Cavin Craft.

Video profil tersebut akan dipublikasikan di setiap media komunikasi pemasaran, seperti website maupun media sosial yang dimiliki. Tahap pendampingan selanjutnya adalah dengan membuat website untuk Paguyuban Batik Pendopo Desa Jarum.

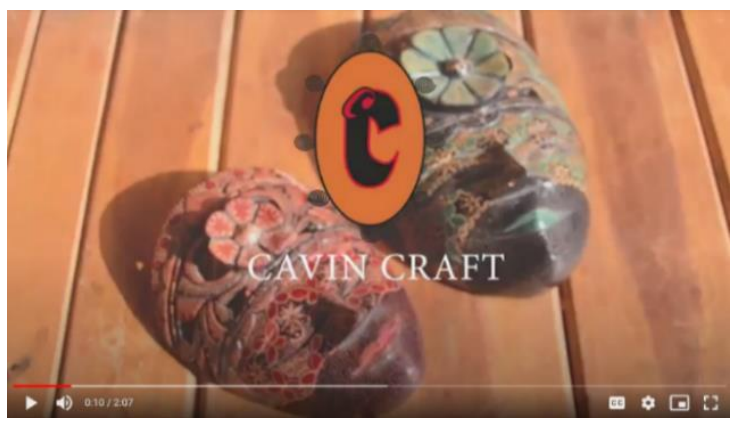

Gambar 7. Cuplikan di video profil

\section{Cavin Craft}

Website Paguyuban Batik Pendopo Desa Jarum sesuai dengan permasalahan yang dihadapi oleh pengusaha yang tergabung di Paguyuban Batik Pendopo Desa Jarum, yaitu yang berhubungan dengan pemasaran melalui media virtual. Website Paguyuban Batik Pendopo Desa Jarum memiliki beberapa pilihan menu seperti Beranda, Tentang Kami, Anggota Paguyuban, Informasi Penting, dan Kontak Kami.

Dalam rangka untuk memasarkan produk-produk dari Paguyuban Batik Pendopo Desa Jarum secara lebih luas, dalam website tersebut juga disediakan pilihan bahasa, yaitu bahasa Indonesia dan bahasa Inggris.

Website Paguyuban Batik Pendopo Desa Jarum tidak hanya bertujuan untuk memasarkan produk saja, tetapi juga memberikan artikelartikel yang berkaitan dengan aktivitas Desa Wisata Jarum ataupun product knowledge dari produk-produk dari Paguyuban Batik Pendopo Desa Jarum. Contoh dari artikel yang berkaitan dengan product knowledge dari website tersebut adalah artikel tentang cara merawat batik dengan pewarna alam maupun artikel mengenai perbedaan pewarna alami dengan pewarna sintetis atau kimia. Pengetahuan ini diberikan karena salah satu keunggulan dari produk batik kain dari Paguyuban Batik Pendopo Desa Jarum adalah pewarna yang didapatkan dari pewarna alam.

Informasi lainnya yang diberikan pada website sesuai dengan tujuan pemasaran adalah galeri produk- 
produk dari pengrajin yang tergabung dalam Paguyuban Batik Pendopo Desa Jarum. Pada menu ini, produk-produk terkelompokkan

berdasarkan kelompok usaha bersama (Kube). Website ini juga terkoneksi dengan blog dari setiap Kube di Paguyuban Batik Pendopo Desa Jarum. Dengan terhubunganya website dengan blog setiap Kube, memungkinkan audience untuk mengetahui harga secara transparan dan juga informasi bagaimana memesan produk tersebut. Ini tentu sangat membantu dalam pemasaran, baik bagi Kube maupun bagi audience yang ingin membeli produk tersebut.

Website tersebut juga terdapat peta atau lokasi dari Desa Jarum dan juga setiap Kube yang ada. Tentunya ini akan mempermudah bagi pengguna website untuk dapat membeli secara langsung. Pengabdi membuat website untuk menjawab permasalahan yang dialami oleh Paguyuban Batik Pendopo Desa Jarum terlebih yang berhubungan dengan pemasaran komunikasi virtual. Kerja sama dalam pembuatan website ini membuktikan bahwa anggota dari Paguyuban Batik Pendopo Desa Jarum sudah memahami pentingnya mengelola pemasaran melalui media komunikasi virtual.
Dalam dunia bisnis, website dalam bentuk e-commerce menjadi kebutuhan untuk pengembangan usahan. Berdasarkan hasil penelitian Oetomo dan Santoso (2015) terkait pemasaran melalui website, menunjukkan bahwa dua merek lebih menarik perhatian konsumen dengan tampilan website yang relatif sama dengan persepsi partisipan, sehingga dapat menarik dan mempertahankan jumlah minat pengunjung website. Selain menggunakan website, untuk menarik minat para calon konsumen dapat juga dilakukan dengan membuat video profile. Video profile menurut Haryoko merupakan media yang efektif untuk mempromosikan produk, daerah atau suatu perusahaan tertentu (Permana, et al). Video profil yang dibuat dalam durasi singkat dan padat dengan berisi berbagai informasi mengenai seluk beluk produk atau usaha bisnis yang dijalankan, dapat berguna bagi orangorang yang melihat. Sehingga semakin dikenal secara luas.

Penggunaan media komunikasi virtual yaitu website sebagai tambahan dalam pemasaran menjadi sesuatu yang baru bagi para anggota Paguyuban Batik Pendopo Desa Jarum. Oleh karenanya, pengabdi membuatkan Buku Panduan Penggunaan Blog dan e-marketplace pada Paguyuban Batik Pendopo Desa Jarum. 


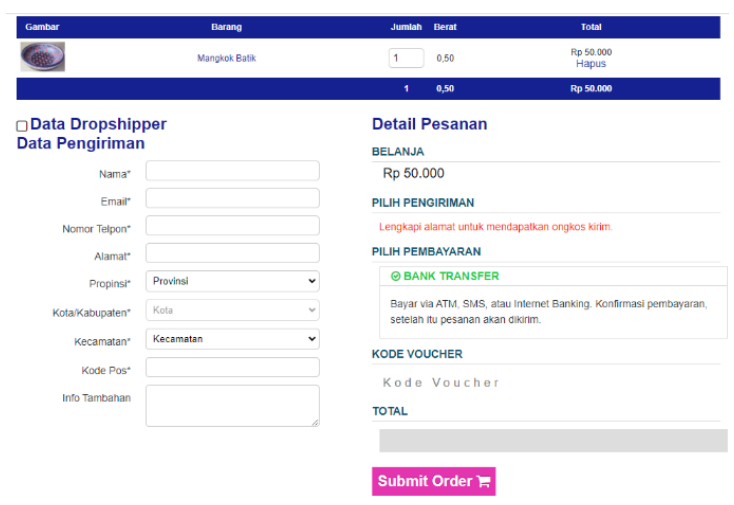

Gambar 8. Order melalui website

Tujuan dari pembuatan buku panduan ini adalah untuk memperbaharui informasi yang dimiliki oleh para anggota dalam memperluas jangkauan pemasaran dan meningkatkan penjualan terlebih di masa pandemi COVID-19. Pada akhirnya, pengrajin yang tergabung dalam kube Paguyuban mampu meningkatkan produktivitas dan daya saing.

Dalam buku tersebut, tidak hanya menjelaskan mengenai bagaimana penggunaan website atau blog untuk mendukung pemasaran virtual, tetapi juga menjelaskan mengenai penggunan e-commerce untuk memperluas pemasaran. Ada beberapa e-commerce yang familiar digunakan di Indonesia, seperti Tokopedia, Shopee, BukaLapak, Lazada, JD.ID, Sociolla, Zalora, dan masih banyak lainnya.

Pengabdi memilih menggunakan Shopee untuk memperluas pemasaran khususnya di pandemi COVID-19 ini sesuai dengan survei yang dilakukan oleh MarkPlus terhadap 500 responden selama Juli-September 2020. Pada survei tersebut, peringkat pertama e-commerce yang dipilih oleh responden selama pandemi COVID-19 adalah Shopee (Setyowati, 2020). Survei tersebut didukung dengan pernyataan bahwa terdapat kenaikan transaksi di Q2- 2020 sebesar 130\% dibanding dengan periode yang sama pada tahun lalu (Haryanto, 2020).

Pemasaran dengan pemanfaatan internet perlu ditingkatkan. Saat ini pemasaran tidak hanya dapat dilakukan secara konvensional bertemu langsung dengan pembeli, namun dapat dilakukan secara online. Apalagi telah banyak platform yang dapat di manfaatkan untuk memasarkan produk secara online, seperti adanya e-commerce. E-commerce sendiri merupakan proses jual-beli produk secara elektronik dengan komputer sebagai perantara transaksi bisnis. (Maulana, Susilo, Riyadi, 2015).

Dengan memberikan panduan penggunaan dan pengelolaan Shopee, pengabdi melakukan pendampingan untuk pembuatan akun Shopee dan pengelolaan akun tersebut. Salah satu Kube yang masih eksis pada saat pengabdi melakukan pendampingan 
adalah Kube Putri Kawung. Oleh karena itu, pengabdi membuat akun Shopee untuk Kube Putri Kawung.
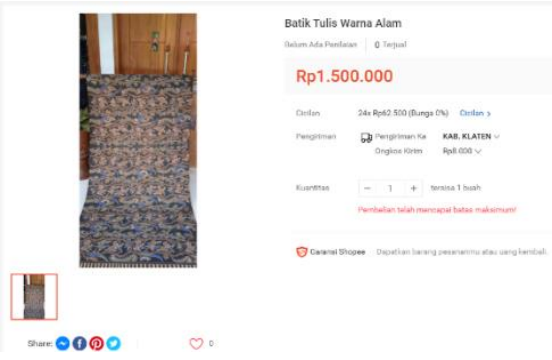

Gambar 9. Contoh Postingan Batik

Putri Kawung di Shopee

Pengabdi

melakukan

pendampingan sampai pada pemostingan produk-produk di platform Shopee. Tidak hanya itu, pengabdi juga memberikan pendampingan kepada kube untuk mampu menuliskan deskripsi produk dengan baik, sehingga tercipta transparansi produk. Dengan buku panduan yang telah ada dan dengan pendampingan pada saat memasarkan melalui Shopee, diharapkan Kube Putri Kawung maupun para anggota Paguyuban Batik Pendopo Desa Jarum mampu menggunakan dan mengelola akun Shopee dengan baik.

\section{PENUTUP}

\section{Simpulan}

Pengabdian Masyarakat yang dilakukan di Paguyuban Batik Pendopo Desa Jarum, Bayat, Klaten terfokus pada komunikasi pemasaran berbasis virtual. Hal ini dilakukan mengingat adanya pandemi COVID-19 yang membuat pengrajin mengalami penurunan penjualan. Produk yang ada di Paguyuban Batik Pendopo Desa Jarum adalah batik kain seperti batik tulis, batik cap, tas batik, dompet batik, dan batik kayu seperti topeng batik kayu, dan interior dengan hiasan batik kayu.

Para anggota Paguyuban Batik Pendopo Desa Jarum memiliki semangat untuk terus merintis usaha batik yang telah lama mitra geluti. Tetapi, dengan pengetahuan yang terbatas mengenai komunikasi pemasaran virtual, peningkatan penjualan tidak dapat dicapai dengan baik. Hal tersebut ditambah dengan adanya kebijakan untuk mengurangi mobilitas karena adanya pandemi COVID-19.

Oleh karena itu, komunikasi pemasaran secara virtual sangat diperlukan untuk tetap mampu bertahan. Paguyuban Batik Pendopo Desa Jarum pada awalnya mengandalkan word of mouth sebagai komunikasi pemasaran. Tentu hal ini tidak efektif.

Dengan adanya pemahaman bahwa pentingnya penggunaan media komunikasia pemasaran virtual, maka mitra akan menggunakan fasilitas yang diberikan dengan sebaik-baiknya. 
Capaian dalam pengabdian masyarakat ini berupa pembuata video profil sebagai konten pemasaran, pembuatan website dan blog, serta pembuatan e-commerce Shopee.

\section{Saran}

Pengurus Paguyuban Batik Pendopo Desa Jarum diharapkan mampu meningkatkan komunikasi pemasaran secara virtual. Diseminasi pesan tersebut pun harus terus disampaikan, sehingga seluruh anggota benar-benar paham akan pentingnya komunikasi pemasaran virtual. Pengurus juga harus memberikan pendampingan dalam pengelolaan komunikasi pemasaran virtual. Bagi pemerintah daerah maupun stakeholder yang terkait diharapkan mampu terus meningkatkan bermacam inovasi dari komunikasi pemasaran virtual bagi Paguyuban Batik Pendopo Desa Jarum terlebih dalam menghadapi situasi yang tidak menentu seperti adanya pandemi COVID-19.

\section{UCAPAN TERIMA KASIH}

Penulis mengucapkan terima kasih kepada Lembaga Penelitian dan Pengabdian kepada Masyarakat Universitas Pembangunan Nasional "Veteran" Yogyakarta, Indonesia yang telah memberikan dukungan untuk pengabdian kepada Paguyuban Batik Pendopo Desa Jarum. Ucapan terima kasih juga kami sampaikan kepada pengurus Paguyuban Batik Pendopo Desa Jarum dan pengurus Desa Jarum atas kerja sama dan kontribusinya dalam pengabdian masyarakat ini.

\section{DAFTAR PUSTAKA}

Huda, Larissa. 2020. IdEA : Kenaikan Penjualan e-commerce 25\% selama Pandemi. Diakses di https://bisnis.tempo.co/read/14 04513/idea-kenaikan-penjualane-commerce-25-persen-selamapandemi/full\&view $=$ ok

Imandiar, Yudistira. 2020. Masa Pandemi, Transaksi Shopee di Q2 2020 Naik hingga 1130\%”. Diakses di https://inet.detik.com/cyberlife/ d-5155740/masa-pandemitransaksi-shopee-di-q2-2020naik-hingga-130

Kabupaten Klaten.2021.Visi dan Misi Kabupaten Klaten. dalam https://klatenkab.go.id/visidan-misi-3/ diakses tanggal 4 Maret 2021

Kancana, Sauptika., Puji Lestari., dan Fera Nurficahyanti. 2016. Model Komunikasi Pemasaran untuk Pemberdayaan Perempuan pada Sektor Informal di 
Yogyakarta. Yogyakarta :

Universitas Pembangunan

Nasional "Veteran" Yogyakarta.

http://jurnalaspikom.org/index. php/aspikom/article/view/94/9

$\underline{\mathrm{O}}$

Maulana,Shabur Miftah., Susilo, Heru., Riyadi. (2015). Implementasi E-Commerce Sebagai Media Penjualan Online (Studi Kasus Pada Toko Pastbrik Kota Malang). Jurnal Administrasi Bisnis (JAB)., 29 (1), 1-9.

Oetomo, Budi S.D., Singgih Santoso., (2015). Pengaruh Web Dalam Komunikasi Pemasaran Untuk Meningkatkan Perhatian Dan Ketertarikan Konsumen Online. Jurnal EKSIS. (8) 2, 94-106.

Keputusan Presiden. 1998. Kepres No. 99 Tahun 1998 tentang Bidang/Jenis Usaha yang Dicadangkan untuk Usaha Kecil dan Bidang/Jenis Usaha yang Terbuka untuk Usaha Menengah atau Usaha Besar dengan Syarat Kemitraan.Jakarta.

Pemerintah Daerah Kabupaten
Klaten.2018.

Rencana

Pembangunan Jangka

Menengah Daerah Kabupaten Klaten Tahun 2016-2021.Klaten. diakses

http://ppid.klatenkab.go.id/

tanggal 4 Maret 2021

Pemerintah Indonesia.2012.Amanat Undang-Undang Nomor 12 Tahun 2012 tentang Pendidikan Tinggi.Jakarta

Permana, A.A.J., et al., Video Profil Sebagai Sarana Promosi Efektif Dalam Menunjang Eksistensi Program Studi Manajemen Informatika. Jurnlal Sain \& Teknologi. (6) 2; 238-247

Sari, Yulia., dan Nadia Wasta Utami. 2021. Komunikasi Pemasaran Digital sebagai Tantangan Teknologi. Jurnal Mahasiswa Komunikasi Cantrik. 1(1). 1-14

Setyowati.Desi. 2020. 'Senjata Shopee Geser Posisi Tokopedia saat Pandemi Corona. Di akses di https://katadata.co.id/desysetyo wati/digital/5f63494f10287/senj ata-shopee-geser-posisitokopedia-saat-pandemi-corona 